\title{
DESAŤ AUTOROV HLADÁ RIEŠENIE PROBLEMATICKÉHO VZŤAHU LINGVISTIKY A TRANSLATOLÓGIE
}

BOISSEAU, Maryvonne - CHAUVIN, Catherine - DELESSE, Catherine - KEROMNES, Yvon (eds.): LINGUISTIQUE ET TRADUCTOLOGIE : LES ENJEUX D'UNE RELATION COMPLEXE. Arras: Artois Presses Université 2016. 200 s. ISBN 978-2-84832-244-5.

Desat' autorov, lingvistov a translatológov zároveň, hl’adá teoretickú a pragmatickú komplementárnost' v náročnom a vel'mi podnetom vzt'ahu lingvistiky a translatológie v období, ked’ si obidve disciplíny nanovo kladú otázky o vlastných epistemologických základoch, vývoji a vzt'ahoch s príbuznými vedami. Digitálne technológie, prístup k vel'kým súborom dát a rozvoj kognitívnych vied a neurolingvistiky značne menia tradičnú lingvistiku a ovplyvňujú aj translatológiu, ktorá musí venovat' pozornost' nielen práci prekladatel'ov s komparatívnymi a paralelnými korpusmi, ale i novým prístupom v oblasti sociológie, filozofie, recepcie či v problematike subjektivity prekladatel'a a kolektívneho prekladu. Je preto pochopitel'né, že vzt’ah lingvistiky a translatológie je chvíl'ami otvorený, chvíl'ami napätý a inokedy viazne.

Predmet skúmania obidvoch disciplín sa čiastočne prelína, a tak sa l’ahko ocitajú vo vzájomnej konkurencii, pričom translatológia sa často pokladá za akýsi „konkrétnejší“ spôsob uchopenia lingvistických problémov. Ved' viacerí lingvisti a teoretici prekladu v jednej osobe (Georges Mounin, Katharina Reiss, Jean-René Ladmiral a iní) tvrdia, že lingvistika je pre translatológiu jednou z rozhodujúcich vied, pretože preklad nie je len, ale predovšetkým jazykovou operáciou. Tento „blízky vzt’ah“ sprevádza translatológiu od 60. a 70. rokov 20. storočia, ked' sa teoretické myslenie späté s prekladom začína vymedzovat' ako samostatná disciplína pod názvom translation studies (James Stratton Holmes, 1972, The Name and Nature Translation Studies), hoci združuje rozmanité teoretické, lingvistické, historické i didaktické orientácie. Problematické vymedzenie predmetu translatológie spôsobuje, že jej epistemologické postavenie je oproti lingvistike stále skôr neisté. Translatológia (po francúzsky traduktológia - traductologie), či ešte lepšie jej podoba zúžená na preklad, sa bud' ocitá v službách lingvistiky, zásobuje ju príkladmi, ktoré lingvistike slúžia ako základ teoretického experimentovania, alebo vychádza z lingvistiky, predovšetkým z porovnávacej lingvistiky, ktorá jazyk originálu a jazyk prekladu nielen opisuje, ale hlavne ponúka transformačnú analýzu prechodov od jedného jazyka k druhému. Lenže lingvistická analýza nemôže obsiahnut' všetky sociokultúrne, štylistické a situačné parametre, ktoré transformáciu ovplyvňujú, a analýza prekladu sa zase nevyhne lingvistickej analýze (okrem literárnoteoretickej a hermeneutickej kritiky prekladu). Ale na rozdiel od lingvistky, ktorá svoj predmet skúma pomocou interných postupov, ktoré sú systému vlastné, translatológia sa situuje v medzijazykovej perspektíve a skúma, ako fungujú dva jazykové systémy v konkrétnych jazykových prejavoch, no všíma si aj prax prekladania, ktorej pravidlá sú z lingvistického hl'adiska stále pomerne nepredvídatel'né. Jednako však majú teoretické výstupy obidvoch disciplín vlastné didaktické, technické a informatické aplikácie (odlišné vzdelávacie programy pre lingvistov a prekladatel'ov, odlišné programy na vyhl'adávanie informácií a extrakciu údajov, nástroje pre počítačovo podporovaný preklad). Obidve sa vymedzujú ako samostatné disciplíny a predovšetkým v osemdesiatych rokoch, ked' sa do popredia dostáva komunikačný a interkultúrny aspekt prekladu, translatológia vo vzt’ahu k lingvistike vyhranene odmieta akýkol'vek vzt’ah subordinácie. 
Súčasný rozvoj informačných technológií (korpusy, automatické spracovanie jazyka) ich však opät' posúva bližšie k sebe a nanovo otvára otázku ich postavenia v súčasnom interdisciplinárnom kontexte humanitných a spoločenských vied.

Nepopieratel'ná interakcia lingvistky a translatológie tak ponúka nové epistemologické, teoretické a metodologické výzvy, na ktoré reaguje desat' príspevkov, ktoré zostavovatelia zaradili do posudzovanej publikácie preto, že sa venujú prieniku translatológie s viacerými lingvistickými teóriami (saussurovskou, guillemin-flescherovskou, enonciatívnou, kognitívnou či sémanticko-interpretačnou), tiež preto, že ich autori podopierajú svoje úvahy konkrétnymi príkladmi z vel'kých korpusov a vyhýbajú sa subjektívnemu hodnoteniu prekladov (medzi angličtinou, francúzštinou, nemčinou a taliančinou), a nakoniec preto, že sa zaoberajú prekladom umeleckým, publicistickým i odborným.

Úvahy o novom ponímaní vzt’ahu lingvistika - traduktológia otvára Jean Szlamowitz a situuje ich v teoretickom rámci hermeneutickej lingvistiky. Pýta sa, v čom spočíva epistemologická osobitost' translatológie a či si vôbec samotné spoločenské vedy nekladú prílišné nároky na vedeckost' (kvantifikácia údajov, využívanie informatiky, matematizácia jazykového prejavu, ktoré autor označuje ako „tiky“). Autor pozoruje asymetriu medzi lingvistikou, ktorej predmetom štúdia je jazyk, a translatológiou, ktorá skúma špecifický jazykový úkon, akým je preklad, pričom translatológiu chápe ako jednu z oblastí vied o jazyku. Zaujíma ho predovšetkým prechod medzi textovým a lingvistickým v takých otázkach, ako je norma, typ textu, štylistický útvar, a nie iba referencia. Zaujíma ho ,poetický rozmer“ translatológie, to, ako faktor kultúry vstupuje do sémantiky.

Otázkou, ako je to s „vedeckost'ou“ humanitných vied, začína svoj príspevok Yvon Keromnes, v ktorom sa snaží prepojit' čisto teoretické úvahy s premýšl'aním prekladatel'ov a s pozorovaním empirických údajov. Opiera sa pritom o preklad Freudovho textu z nemčiny do angličtiny a francúzštiny. Vzt’ah medzi zvoleným teoretickým prístupom a výberom prekladatel'ských riešení je vel'mi variabilný - kým niektoré lingvistické koncepcie prekladatelia prijímajú alebo odmietajú, praktická konfrontácia s konkrétnym dielom dokáže zmarit' akékol'vek apriórne teoretizovanie. V takejto metateoretickej perspektíve autorka poukazuje na rozpad lingvistky ako vednej disciplíny (generatívna verzus kognitívna lingvistika) porovnatel'ný s roztrieštenost'ou translatológie, čo nevyhnutne vedie k otázke, či je vôbec možné vymedzit', čo prináleží skúmat' lingvistike a čo translatológii.

Susanne Pauer poukazuje na teoretický stereotyp arbitrárnosti, ktorým prekladatelia zdôvodňujú, že v prekladoch francúzskych komiksov do angličtiny a nemčiny často vynechávajú preklad zvukomalebných slov. Autorka sa usiluje o postihnutie povahy a symboliky zvukomalebných slov pomocou pojmu arbitrárnosti, motivovanosti a ikonickosti a pokúša sa o ich typológiu na základe symbolických významov, ktoré nesú. Prekladatel'om odkazuje, že v preklade je možné vyhoviet' obsahu i forme zvukomalebných slov.

Ďalší príspevok sa zameriava na schémy nominalizácie $\mathrm{v}$ anglických informačných odborných textoch a v ich prekladoch do francúzštiny. Pierre Lejeune v ňom pripomína, že tak ako je dnes už prekonaný výhradne lingvistický prístup k prekladu, rovnako opatrne treba zaobchádzat's extrémnou orientáciou na komunikačný či kognitívny prístup k prekladu. Autor zdôrazňuje užitočnost' paralelných korpusov pri odhal'ovaní výrazných tendencií vnútri porovnávaných jazykových systémov. Pracuje s paralelným korpusom z oblasti klimatických zmien a odhadov vývoja ekonomickej konjunktúry, v ktorom sleduje referenčnú spol'ahlivost' 
prekladu vel'mi frekventovaných nominálnych syntagiem a všíma si predovšetkým kalky a metonymické posuny spôsobené vzájomným ovplyvňovaním obidvoch jazykov. Analyzuje asymetrie $\mathrm{v}$ tvorení anglických a francúzskych nominálnych syntagiem, ktoré pomenúvajú zmenu, vývoj, transformáciu a uzatvára, že francúzština vyjadruje proces transformácie v jeho globálnosti, kým angličtina rovnaké procesy predstavuje skôr aspektuálne, teda ako perfektívne alebo imperfektívne.

O pragmatický prístup sa usiluje Kate Beeching, ktorá vo svojej porovnávacej štúdii ukazuje, ako môže lingvistka ruka v ruke s translatológiou lepšie ozrejmit' význam a funkcie anglickej lexikálnej jednotky sort of a pomôct' správne ju prekladat' do francúzštiny. Práca s paralelným korpusom jej umožňuje ukázat', ako prekladatel'ova nepresnost' alebo vynechanie tohto diskurzného markera vyvolá významovú variáciu. Autorka zároveň zdôrazňuje prínos translatológie k skúmaniu významu polyfunkčných diskurzných markerov a jeho diachronického vývoja. V pragmatickej lingvistike a vo využívaní vel'kých korpusov vidí možnost' nového prístupu k prekladu, ktorý celkom prirodzene súvisí s pragmatickou lingvistikou, pretože preklad sa nezaobíde bez zohl'adnenia kontextových faktorov.

Natalie Kübler hl'adá prepojenia medzi korpusovou lingvistikou, pragmatickým prístupom k odbornému prekladu a viacjazyčnou terminológiou. Ukazuje postupy, ktorými sa dá osvojit' si pomocou komparatívnych korpusov odborných prejavov istú doménu v miere dostatočnej pre profesionálny odborný preklad a určit’ mieru špecializácie prekladaného textu. Dôraz kladie na perlokučný účinok pragmaticky orientovaného prekladu a terminologickú analýzu, ktorú používanie korpusov výrazne zefektívnilo. Rovnako sa však pokúša nájst' odpoved' aj na otázku, v čom spočívajú obmedzenia korpusovej lingvistiky v odbornom preklade, a konštatuje, že pomocou postupov korpusovej lingvistiky môže prekladatel' znížit' možnost' chybných prekladatel'ských riešení, ale nenahradí nimi chýbajúcu interkultúrnu kompetenciu a hlbšie tematické vedomosti, ktoré sú pri istých druhoch odborného prekladu nevyhnutné.

Zdalo by sa, že vzhl’adom na množstvo publikovaných porovnávacích štúdií o verbálnych kategóriách vidu a času v angličtine a vo francúzštine je v tejto téme t’ažké objavit' niečo nové. Clara Mallier však porovnaním prekladov šiestich románov D. Lehana do francúzštiny dospieva k záveru, že časové prestavby v procese rozprávania, tak ako ich opísal E. Benveniste, využívajú pri preklade anglického préterita rozprávača v prvej osobe čoraz menej francúzsku dvojicu passé simple a passé composé (jednoduchý minulý čas a zložený minulý čas). V piatich zo šiestich analyzovaných prekladov románov sa hlavným časom rozprávača stal passé composé, čím sa v preklade stiera rozdiel medzi príbehom a diskurzom (ja-rozprávač a ja-osoba, ktorá prežila príbeh). Vo francúzštine môže výber jedného alebo druhého času menit' uhol pohl'adu rozprávača, ale to, že passé simple sa dnes zároveň pocit’uje ako príznačný pre vel'mi kultivované používanie jazyka, spôsobuje, že často nevyhovuje potrebnému rečovému registru. Autorka analýzou dokazuje, že korpusová lingvistika môže byt' zaujímavým nástrojom aj pre umelecký preklad.

Aj autor nasledujúceho príspevku Yves Bardière analyzuje literárny preklad a sleduje, ako prekladatelia do angličtiny prekladajú francúzske naračné imperfektum. Korpus pozostáva z troch prekladov toho istého textu J. Verna a autor analýzu vedie v guillemin-flescherovskom duchu skúmania toho, aké hodnoty má imperfektum v sprostredkovaní chronológie udalostí a v napredovaní narácie. Tým vysvetl'uje, prečo prekladatelia uprednostňujú pri prekladaní do angličtiny práve jednoduché préteritum, hoci tak môže dochádzat' $\mathrm{k}$ narušeniu pôvod- 
ných textových hodnôt. Prekladatel'ov upozorňuje, že treba rozlišovat' medzi imperfektívnostou a gramatickou a lexikálnou perfektívnost'ou, ale hlavne ich interakciou. Množstvo analyzovaných príkladov a presnost' analýzy presvedčivo ukazujú, aké dôležité je miesto porovnávacej lingvistiky v uvažovaní o preklade.

Predposledný príspevok predstaveného výberu ponúka zaujímavé prepojenie medzi porovnávacou lingvistikou, variačnou lingvistikou a translatológiou. Giovanna Titus-Brianti v ňom skúma, ako vplýva angličtina na súčasné významy a použivanie talianskej progresívnej perifrázy stare + gerundívum. V taliančine, v ktorej vid nie je vyjadrený autonómne a kategória času a aspektu je v nej vyjadrená synkreticky, ňou prekladatelia často prekladajú anglické $b e+$-ing. Štúdia ponúka dve hypotézy: prvou z nich je tlak anglického originálu na preklad, ktorému prekladatelia a následne ostatní používatelia taliančiny podliehajú, druhou sú zmeny v slovesnom vide taliančiny, ktoré sú v skúmanej syntaktickej štruktúre vplyvom prekladov $\mathrm{z}$ angličtiny iba umocnené. Obidve hypotézy autorka overuje pomocou analytických postupov korpusovej lingvistiky a pracuje s paralelným i komparatívnym korpusom. Korpusové údaje potvrdzujú druhú hypotézu. Vnútorné systémové zmeny predchádzali zmenám samotnej syntaktickej štruktúry a jej frekvencia rastie iba v odborných prekladoch z angličtiny. Autorka uzatvára, že treba rozlišovat' medzi vplyvom a výpožičkou, a upozorňuje na relatívnu nepriepustnost' jazykov v syntaktickej rovine.

Sériu príspevkov uzatvára Maryvonne Boisseau syntézou o vedeckom bádaní Jacqueline Guillemin-Flescherovej, ktoré sa o objasnenie problematického vzt'ahu medzi lingvistikou a translatológiou usiluje pomocou údajov získaných z paralelných a komparatívnych korpusov. Porovnávaním vel'kého objemu anglických a francúzskych textov rozmanitého obsahového a žánrového zamerania sa Guillemin-Flescherová snaží dokázat', že každý jazyk uplatňuje vlastné charakteristické stratégie, ktoré označuje ako kolektívne jazykové správanie. Ide teda o normy a špecifiká - kolektívne rekurentné diskurzné schémy výstavby diskurzu, ktoré je možné odhalit' len porovnaním jazykov pomocou dostatočne vel'kých korpusov. Autorka príspevku poukazuje na fakt, že lingvistický porovnávací prístup v translatológii je stále aktuálny a vzt’ah medzi lingvistikou a translatológiou je nevyhnutný. Teóriu GuilleminFlescherovej konfrontuje s teoretickými závermi uznávaného translatológa J.-R. Ladmirala a uzatvára, že z epistemologického, metodologického a kultúrneho hl’adiska sú interakcie a tenzie medzi obidvomi disciplínami stimulom pre ich d'alší rozvoj. Oceňuje subtílnost' a rigoróznost' jej multivariačnej analýzy opierajúcej sa o teóriu predikatívnych a enunciatívnych operácií Antoina Culioliho a vernost' celoživotnému presvedčeniu, že komparatívna lingvistika pomáha zvyšovat' schopnost' prekladatel'a vymedzit' a vyriešit' konkrétne problémy v procese prekladania a racionálne usudzovat' o jeho výsledku.

Výberom príspevkov sa zostavovatelia snažia ukázat', že lingvistika a translatológia môžu spolu a každá svojím vlastným spôsobom prispiet' $k$ prehĺbenej analýze jazykov a textov a k d’alšiemu využitiu takto získaných poznatkov. Synergia v uvažovaní predstavených desiatich autorov nám presvedčivo ukazuje potrebu teoretickej aj pragmatickej komplementárnosti obidvoch disciplín, ktorú dnes často spochybňujú zástancovia autonómnej translatológie usilujúci o jednotnú translatologickú teóriu. 